\title{
Factor Analysis of Ownership Behavior at Family Business: The Case of Indonesia
}

\author{
Denny Bernadus ${ }^{1}$, Christina Whidya Utami $^{2}$, Liliana $^{3}$
}

\begin{abstract}
:
There are many family business in Indonesia that cannot survive after the third generation. One of the factors affecting the inability to survive after the third generation can be attributed to process of succession.
\end{abstract}

Ther are several stages involved in the arrangement of a successor. The successor induction, followed by the phasing out of the predecessors' role, until the successor is ready to take a full leadership are factors which play an important role and they are also part of other important elements of ownership behavior. Ownership behavior is a factor to balance the privileges of ownership, such as wealth, power, joy, source of motivation, related to the task and ownership risks, including proper concern for the corporate wellbeing and accountability for corporate success.

This study explores the factors regarding ownership behavior, which is professionalism, active governance, owner as a resource and basic duty. The sample of this research is 49 respondents of family business owners.

The research uses factor analysis to prove that all indicators developed professionalism, active governance, owners as resources and basic duties, which at the end, proves that professionalism, active governance, owners as the resources and basic duties significantly develop the ownership behavior family business factor in Indonesia producing four new factors, namely professional governance, main duties, owner responsibility and professional activities.

Keywords: Professionalism, active governance, owners as resources, basic duties, and ownership behavior.

\footnotetext{
${ }^{1}$ Lecturer, Department of International Business Management, Ciputra University Indonesia, denny@ciputra.ac.id

${ }^{2}$ Lecturer, Department of International Business Management, Ciputra University Indonesia whidyautami@ciputra.ac.id

${ }^{3}$ Lecturer, Department of International Business Management, Ciputra University Indonesia ldewi@ciputra.ac.id
} 


\section{Introduction}

Family business is a fragile business if not managed professionally. In Indonesia right now, there are more family business that cannot survive after the third generation. Unlike most business, in family business there is a strong kinship factor that affects the performance of its management. Based on Price Waterhouse \& Coopers (PwC) survey in May 2015, more than 95\% of the businesses in Indonesia are family oriented (PwC, 2015). The presence of emotional bond from the upper management whom still have a kinship relationship, often hampers progress because often professional relationship is followed by conflicts to fulfil personal needs.

One of the factors affecting the inability to survive after the third generation is failing on the process of succession. Succession between generations does not often work well. Most often, the second generation still understand the kinship from the first generation, thus the business can keep growing. However, the third generation who was born on a much different culture from the previous generation is often less wise. The existence of a family member who does not understand about business well caused a decline that resulted in the deconstruction of family business. One of the hindrances is closure of family business to outsiders as top leaders (Utami et al., 2017).

Breton-Miller et al. (2004) suggest that a good succession is a competitive succession. Succession refers to the extent which the successor is able to demonstrate competence to gain employment and leadership in the family business; kinship alone does not guarantee employment or the privilege of leading the family business. Chittor and Das (2007), state that a tight selection process from the successor and compliance with meritocracy, including external evaluation, coaching, and experiences of family member to achieve management position, are important.

The arrangement of successor and the successor induction followed by the phasing out of the predecessors' role, until the successor is ready to take a full leadership are all factors that play an important role (Breton-Miller et al., 2004) and these are also part of important elements of ownership behavior. Ownership behavior is a factor believed to balance the privileges of ownership, such as wealth, power, joy, source of motivation, etc., related to the task and ownership risks, including proper concern for the corporate wellbeing and accountability for corporate success (Aminoff et al., 2004; Baldacchino et al., 2017) .

Several aspects that will be seen in this research is a model development of ownership behaviors family business in Ciputra University. This aspect is necessary for long-standing family businesses not to be lost, but to be more sustainable. According to Berent et al. (2014), there are four types of ownership behavior. There are professionalism, active governance, owners as a resources and basic duties. Factors regarding ownership behavior are professionalism, which positively affects the business performance, act in accordance with the expectations and agreements 
between owner as resources and basic duties in relation to the company. The effect of active governance towards the business performance is moderated by business size (Berent et al., 2012).

\section{Family Business Management}

Family business is a business owned and/or managed by a group of people who have kinship relationship, such as husband-wife or its generation, including brotherly relationship. Handoyo (2010) stated that a well family business management, either in a big or small scale, can often be influenced by situations that develop within the family context. Family business is a company where the highest power exists on family control: the founder has a desire to pass on to his descendant. According to the World Bank Group (2011), some family business strengths are:

1) Commitment: The owner shows his/her highest dedication in seeing the business grow, prosper, thus it will be able to be passed on to the next generation.

2) Knowledge Continuity: Family's knowledge accumulation, experiences and skills are passed on to the next generation.

3) Reliability and Pride: Several weaknesses of family business are:

a) Complexity: Family business is often more complex in terms of corporate governance compare to other type of businesses due to the presence of family factors (e.g. emotion, different roles, etc), creating difficulties to make a decision.

b) Informality: Most family business, especially in the first and second generation, are less interested in making a clear procedure. However this situation can create a lot of inefficiencies and internal conflict that can threaten the business continuity as business grows up.

c) Lack of discipline: Most family business delay or even ignore strategic decision, such as determining the CEO, and the planning for succession, which can lead to business failure. On other types of businesses, each individual has a clear role as employees, managers, owners or directors. However, the role division in a family business if more complex; each individual can have several roles and responsibilities with different incentives (World Bank Group, 2011).

Figure 1: Ownership Behaviors Variables Dimension

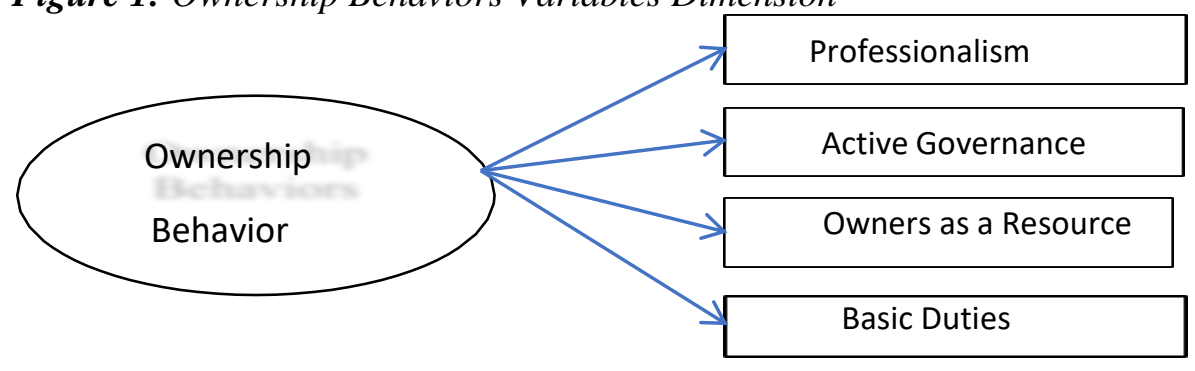

Source: Berent- Braun and Uhlaner (2012). 
Therefore the problem in this research is formulated as follows: Are professionalism, active governance, owners as a resource and basic duties factors of ownership behaviors?

\section{Analyzing Data}

The object of this research is family businesses at family business class in Ciputra University. The scope of the research is on the factors of ownership behavior. The total number of family businesses at the family business class in Ciputra University is 75 , with a turnover of about 300 million to 2.5 billion. The size of the population is also used as the sample group in this study. Data submission in this study was conducted by observation and interview via questionnaires that have been designed and prepared for this research. The data obtained are primary data collected from conducting interviews with the respondent. Then, the secondary data are obtained via existing reports.

Factors regarding ownership behavior consist of: professionalism, active governance, owners as a resource, and basic duties. Confirmatory Factor Analysis (CFA) is used to prove which of professionalism, active governance, owners as a resource, and basic duties are factors of ownership behavior. Below is the descriptive statistic for each respondent's answer based on the questions being asked.

Table 1. Description of Respondent's Answers

\begin{tabular}{|c|c|c|c|c|c|}
\hline $\begin{array}{l}\text { Co } \\
\text { de }\end{array}$ & Description & Min & $\begin{array}{l}\mathrm{Ma} \\
\mathrm{x}\end{array}$ & $\begin{array}{l}\text { Mea } \\
\mathrm{n}\end{array}$ & $\begin{array}{l}\text { Standa } \\
\text { rd } \\
\text { Deviati } \\
\text { on }\end{array}$ \\
\hline \multicolumn{6}{|c|}{ PROFESIONAL } \\
\hline $\begin{array}{l}\mathrm{X}_{1} \\
1.1\end{array}$ & $\begin{array}{l}\text { The owner is involved in the internal business } \\
\text { matters only if it has officially agreed that the } \\
\text { job is part of his/her responsibility. }\end{array}$ & 1.00 & 5.00 & 3.58 & 1.182 \\
\hline $\begin{array}{l}\mathrm{X}_{1} \\
1.2\end{array}$ & $\begin{array}{l}\text { The owner behaves in a ways that respects the } \\
\text { hierarchy and the authority of the business }\end{array}$ & 1.00 & 5.00 & 4.13 & 0.866 \\
\hline $\begin{array}{l}\mathrm{X}_{1} \\
1.3\end{array}$ & $\begin{array}{l}\text { The owner is ready to take action in cases } \\
\text { where the supervisory board and/or the } \\
\text { management team does not carry the job } \\
\text { properly. }\end{array}$ & 2.00 & 5.00 & 4.42 & 0.738 \\
\hline $\begin{array}{l}\mathrm{X}_{1 .} \\
1.4\end{array}$ & $\begin{array}{l}\text { The owner is clear about their intentions } \\
\text { regarding their future investment on their } \\
\text { business. }\end{array}$ & 1.00 & 5.00 & 4.25 & 0.978 \\
\hline \multicolumn{6}{|c|}{ ACTIVE GOVERNANCE } \\
\hline $\begin{array}{l}\mathrm{X}_{1} \\
2.1\end{array}$ & $\begin{array}{l}\text { The business owner acts consistently to the } \\
\text { expectation implied by the shareholder } \\
\text { agreements or other relevant agreements. }\end{array}$ & 1.00 & 5.00 & 4.06 & 0.782 \\
\hline
\end{tabular}




\begin{tabular}{|c|c|c|c|c|c|}
\hline $\begin{array}{l}\mathrm{X}_{1} \\
2.2 \\
\end{array}$ & $\begin{array}{l}\text { The owner holds the key role to monitor the } \\
\text { management work. }\end{array}$ & 3.00 & 5.00 & 4.33 & 0.724 \\
\hline $\begin{array}{l}\mathrm{X}_{1} \\
2.3\end{array}$ & $\begin{array}{l}\text { The owner engages in many efforts beyond } \\
\text { what is expected to help the business to be } \\
\text { successful. }\end{array}$ & 1.00 & 5.00 & 4.21 & 0.849 \\
\hline \multicolumn{6}{|c|}{ OWNER AS RESOURCE } \\
\hline $\begin{array}{l}\mathrm{X}_{1} \\
3.1\end{array}$ & $\begin{array}{l}\text { The owner is very enthusiastic to talk about } \\
\text { their business. }\end{array}$ & 2.00 & 5.00 & 4.38 & 0.732 \\
\hline $\begin{array}{l}\mathrm{X}_{1} \\
3.2\end{array}$ & $\begin{array}{l}\text { The owner makes him/herself to be a resource } \\
\text { for the business. }\end{array}$ & 3.00 & 5.00 & 4.40 & 0.676 \\
\hline $\begin{array}{l}X_{1} \\
3.3 \\
\end{array}$ & $\begin{array}{l}\text { The owner keeps their investment in the } \\
\text { business as long as the time they takes. }\end{array}$ & 1.00 & 5.00 & 4.29 & 0.849 \\
\hline \multicolumn{6}{|c|}{ BASIC DUTIES } \\
\hline $\begin{array}{l}X_{1} \\
4.1\end{array}$ & $\begin{array}{l}\text { The owner knows the amount of business } \\
\text { profits that they gained in the last five years. }\end{array}$ & 2.00 & 5.00 & 4.33 & 0.753 \\
\hline $\begin{array}{l}X_{1} \\
4.2 \\
\end{array}$ & $\begin{array}{l}\text { The owner knows the average profitability in } \\
\text { the last five years. }\end{array}$ & 2.00 & 5.00 & 4.33 & $\begin{array}{l}0.7532 \\
4 \\
\end{array}$ \\
\hline $\begin{array}{l}X_{1} \\
4.3 \\
\end{array}$ & $\begin{array}{l}\text { The owner is aware of changes in the value of } \\
\text { family assets over the last five years. }\end{array}$ & 2.00 & 5.00 & 4.38 & $\begin{array}{l}0.7329 \\
6\end{array}$ \\
\hline $\begin{array}{l}\mathrm{X}_{1} \\
4.4\end{array}$ & $\begin{array}{l}\text { The owner is up-to-date with the business' } \\
\text { progress, for example reading reports about } \\
\text { the business. }\end{array}$ & 2.00 & 5.00 & 4.19 & $\begin{array}{l}0.8418 \\
9\end{array}$ \\
\hline $\begin{array}{l}\mathrm{X}_{1} \\
4.5\end{array}$ & $\begin{array}{l}\text { The owner regularly attends shareholder } \\
\text { meetings or other formal meetings that } \\
\text { involves business' owners. }\end{array}$ & 1.00 & 5.00 & 3.85 & $\begin{array}{l}0.9222 \\
9\end{array}$ \\
\hline
\end{tabular}

Source: Processed by the researchers, 2017.

According to Table 1, almost all indicators have a mean score of 4 and above with the answer scale being between 1 to 5 . It indicates that on average, respondents' answer is 'agree'. The lowest mean score and highest standard deviation of respondents' answer if found in indicator $\mathrm{X}_{1.1 .1}$ (The owner is involved in the internal business matters only if it has officially agreed that the job is part of his/her responsibility) with a standard deviation of 1.18202, which means that the average of respondents' answer is only close to neutral with a diverse and variety of answers because it has a high standard deviation. In the following sections we will discuss the results and the discussion of each variable.

\section{Professional Variable:}

Table 2 is the result of KMO and Bartlett's test. It can be seen that the value of KMO Measure of Sampling Adequacy (MSA) is 0.509. Because the MSA value is above 0.5 the set of variables can be further processed (Hair et al., 2008). Furthermore, each variable is analyzed to know which data can be further processed and which should be issued. A similar result is also found, and can be seen from the KMO and Bartleett's test (which is shown with the Chi-Square number) of 53.169 with a significance level of 0.000 . 
Table 2. KMO and Bartlett's Test ${ }^{a}$

Kaiser-Meyer-Olkin Measure of Sampling Adequacy.

Bartlett's Test of Sphericity

Approx. Chi-Square

.509

53.169

df

Sig.

6

.000

\section{Active Governance:}

Table 3 shows the KMO and Bartlett's test. The KMO Measure of Sampling Adequacy (MSA) is 0.509. Because the value of MSA is above 0.5 the group of variables can be processed further. Furthermore, each variable is analyzed to know which data can be further processed and which should be issued. Similar result is also found and can be seen from the KMO and Bartleett's test (which is shown with the Chi-Square number) of 60.967 with a significance level of 0,000 .

Table 3. KMO and Bartlett's Test ${ }^{a}$

Kaiser-Meyer-Olkin Measure of Sampling Adequacy.

Bartlett's Test of Sphericity

Approx. Chi-Square

.676

60.967

df

3

Sig.

.000

\section{Owner Resources:}

Table 4 shows the KMO and Bartlett's test. The KMO Measure of Sampling Adequacy (MSA) is 0.509. Because the value of MSA is above 0.5 the group of variables can be processed further. Furthermore, each variable is analyzed to know which data can be further processed and which should be issued. Similar result is also found and can be seen from the KMO and Bartleett's test (which is shown with the Chi-Square number) of 71.089 with a significance level of 0.000

Table 4. KMO and Bartlett's Test ${ }^{a}$

\begin{tabular}{|c|c|c|}
\hline \multicolumn{2}{|c|}{ Kaiser-Meyer-Olkin Measure of Sampling Adequacy. } & .742 \\
\hline \multirow{3}{*}{ Bartlett's Test of Sphericity } & Approx. Chi-Square & 71.089 \\
\hline & $\mathrm{df}$ & \\
\hline & Sig. & .000 \\
\hline
\end{tabular}

\section{Basic Duties:}

Table 5 shows the KMO and Bartlett's test. The KMO Measure of Sampling Adequacy (MSA) is 0.509. Because the value of MSA is above 0.5 the group of variables can be processed further. Furthermore, each variable is analyzed to know which data can be further processed and which should be issued. Similar result is 
also found and can be seen from the KMO and Bartleett's test (which is shown with the Chi-Square number) of 99.098 with a significance level of 0.000

Table 5. KMO and Bartlett's Test ${ }^{a}$

Kaiser-Meyer-Olkin Measure of Sampling Adequacy.

.805

Approx. Chi-Square

df

Sig.
99.098

10

.000

\section{Ownership Behavior:}

Table 6 shows the KMO and Bartlett's test. The KMO Measure of Sampling Adequacy (MSA) is 0.509 . Because the value of MSA is above 0.5 the group of variables can be processed further. Furthermore, each variable is analyzed to know which data can be further processed and which should be issued. Similar result is also found and can be seen from the KMO and Bartleett's test (which is shown with the Chi-Square number) of 466.919 with a significance level of 0,000

Table 6. KMO and Bartlett's Test ${ }^{a}$

\begin{tabular}{|c|c|c|}
\hline \multicolumn{3}{|c|}{ Kaiser-Meyer-Olkin Measure of Sampling Adequacy. } \\
\hline \multicolumn{2}{|c|}{$\begin{array}{l}\text { Kaiser-Meyer-Olkin Measure of Sampling Adequacy. } \\
\text { Approx. Chi-Square } \\
\text { Bartlett's Test of Sphericity } \\
\text { df }\end{array}$} & 120 \\
\hline & Sig. & \\
\hline
\end{tabular}

Based on the results in Tables 2 to 6 we can make the following comments:

Professional variable includes four indicators, all becoming a valid factor from the variable. This finding is based on the value of KMO and Bartlett's test (that is shown by the value of Chi-Square) of 53.169 with a significance level of 0.000 . From the four factors that are analyzed, it shows that the MSA value is above 0.5 . This means that the variable can be predicted and can be analyzed further. Variable being analyzed can be grouped into 4 factors. A correlation below 0.5 shows a weak correlation, while correlation over 0.5 shows a strong correlation. The Component Matrix shows a distribution of four variables to two factors. Factor 1 consist of variable $\mathrm{X}_{1.1 .1}$ (the owner is involved in the internal business matters only if it has officially agreed that the job is part of his/her responsibility) and $\mathrm{X}_{1.1 .2}$ (the owner behaves in a way that respects the hierarchy and the authority of the business). Factor 2 consist of variable $\mathrm{X}_{1.1 .3}$ (the owner is ready to take action in cases where the supervisory board and/or the management team does not carry the job properly) and $\mathrm{X}_{1.1 .4}$ (the owner is clear about his/her intention regarding future investment on his/her business).

Active governance variable includes three indicators, all becoming valid from the value of KMO and Bartlett's test (that is shown by the value of Chi-Square) at 
60.967 with significance level of 0,000 . From the three factors that are analyzed, it shows that the MSA is over 0.5. This means that the variable can be analyzed further. Variables that are being analyzed can be grouped into 1 factor, which is eigenvalues, that shows a value bigger than one. With this in hand, one factor is formed with variable $X_{1.2 .1}$. (the business owner acts consistently to the expectation implied by the shareholder agreements or other relevant agreements), $X_{1.2 .2}$ (the owner holds the key role to monitor the management work), $\mathrm{X}_{1.2 .3}$ (the owner engages in many efforts beyond what is expected to help the business to be successful in it).

Owner resource variable covers four indicators. All factors are valid factors from the active governance variable. This is shown by the KMO Measure of Sampling Adequacy (MSA) being 0.509. Because the value of MSA is above 0.5 the variables can be processed further. This means that the variable can be predicted to be analyzed further. All variables can be explained by factors formed with bigger communalities; thus, the bigger communalities the stronger the correlation between them. According to total variance explained figure, variables that are analyzed can be grouped into 1 factor, including variable $\mathrm{X}_{1.3 .1}$ (the owner is very enthusiastic to talk about his/her business). The correlation between variable $\mathrm{X}_{1.3 .1}$. with factor 1 is 0.656 (strong), as well as with variable $\mathrm{X}_{1.3 .2}$ (the owner make himself/herself to be a resource for the business), and $X_{1.3 .3}$ (the owner keeps his/her investment in the business as long as he/she likes).

Basic duties variable includes four indicators, all becoming a valid factor from the active governance variable. This is based on the KMO and Bartlett's test value of 0.509 . Because the MSA value is over 0.5 the variable can be predicted for further analysis. Based on Total Variance Explained, variable being analyzed can be formed into one factor, which is eigenvalues, that shows a value over one. Factor 1 consist of variable $X_{1.4 .1}$ (the owner knows the amount of business profits that they gained in the last five years) and $\mathrm{X}_{1.4 .2}$ (the owner knows the average profitability in the last five years), $X_{1.43}$ (the owner is aware of changes in the value of family assets over the last five years), $\mathrm{X}_{1.44}$ (the owner is up-to-date with the business' progress, for example reading reports about the business) and $X_{1.4 .5}$ (the owner regularly attend shareholder meetings or other formal meetings that involves business' owners).

This finding leads to a discussion of all variables, which are professional, active governance, owner resources, and basic duties being factors of ownership behavior as can been seen below. First, the KMO Measure of Sampling Adequacy (MSA) is 0.509 . Because the MSA value is over 0.5 the variable can be predicted for further analysis. Based on Total Variance Explained, variable that is analyzed is formed into four factors. According to the rotated factor, it is found that variables are grouped info factors as follows:

Factor 1 consists of variable $X_{1.1 .3}$ (the owner is ready to take action in cases where the supervisory board and/or the management team does not carry the job properly) 
and $\mathrm{X}_{1.1 .4}$ (the owner is clear about his/her intentions regarding future investment on his/her business), $X_{1.2 .1}$. (the business owner acts consistently to the expectation implied by the shareholder agreements or other relevant agreements), $\mathrm{X}_{1.2 .2}$ (the owner holds the key role to monitor the management work), $\mathrm{X}_{1.2 .3}$ (the owner engages in many efforts beyond what is expected to help the business to be successful).

Factor 2 consists of variable $\mathrm{X}_{1.4 .1}$ (the owner knows the amount of business profits that they gained in the last five years) and $\mathrm{X}_{1.4 .2}$ (the owner knows the average profitability in the last five years) and $\mathrm{X}_{1.4 .3}$ (the owner is aware of changes in the value of family assets over the last five years).

Factor 3 consists of variable $\mathrm{X}_{1.1 .4}$ (the owner is clear about his/her intention regarding future investment on his/her business), $\mathrm{X}_{1.3 .1}$ (the owner is very enthusiastic to talk about his/her business), $\mathrm{X}_{1.3 .2}$ (the owner makes himself/herself to be a resource for the business), $\mathrm{X}_{1.3 .3}$ (the owner keeps investment in business as long as he/she likes), $\mathrm{X}_{1.4 .4}$ (the owner is up-to-date with the business' progress, for example reading reports about the business) and $\mathrm{X}_{1.4 .5}$ (the owner regularly attends shareholder meetings or other formal meetings that involves business' owners).

Factor 4 consists of variable $\mathrm{X}_{1.1 .1}$ (the owner is involved in internal business matters only if it has officially agreed that the job is part of his/her responsibility) and $\mathrm{X}_{1.1 .2}$ (the owner behaves in a way that respects the hierarchy and the authority of the business).

Remembering that Factor 1 consists of variable $X_{1.1 .3}$ (the owner is ready to take action in cases where the supervisory board and/or the management team does not carry the job properly) and $\mathrm{X}_{1.1 .4}$ (the owner is clear about his/her intention regarding future investment on his/her business), $\mathrm{X}_{1.2 .1}$ (the business owner acts consistently to the expectation implied by the shareholder agreements or other relevant agreements), $\mathrm{X}_{1.2 .2}$ (the owner holds the key role to monitor the management work), $\mathrm{X}_{1.2 .3}$ (the owner engages in many efforts beyond what is expected to help the business to be successful) which shows factor active governance and profession. Thus, factor 1 represents professional governance.

For the same reason because Factor 2 consists of variable $X_{1.4 .1}, X_{1.4 .2}$ and $X_{1.4 .3}$ represents main duties.

Factor 3 consists of $\mathrm{X}_{1.1 .4}, \mathrm{X}_{1.3 .1}, \mathrm{X}_{1.3 .2}, \mathrm{X}_{1.3 .3}, \mathrm{X}_{1.4 .4}$ and $\mathrm{X}_{1.4 .5}$ which mainly shows a mix of factor professional, owner resource and basic duties, thus, factor 3 represents owner responsibilities.

Factor 4 consists of $\mathrm{X}_{1.1 .1}$ and $\mathrm{X}_{1.1 .2}$ which shows a mix of professional factor, thus, factor 4 represents professional activitiy. 
With the result presented, the study found several indicators that build new variables of ownership behavior, which are professional governance, main duties, owner responsibilities and professional activity. The result is in line with the study by Utami et al. (2017), Baer (2007), Basri and Eng (2004) indicating that a good performance or a professional performance of the owner or the successor can be a main consideration to do a succession that creates a positive impact on the family business' performance.

Utami et al. (2017) and Lansberg (1999) stated that one characteristic of the family business is the wish to have a family member as the leader of the business. This characteristic, in general, is based on family's role on the family business, which is to benefit and watch over available resources, set levels of specialization and integrity, facilitate communication and coordination, set responsibility and trust, as well as to set the holder of the company's chairman. By setting rules for the family business management, followed by setting the family members and other workers, a clear job description will define the job limit and the authority of a role. These are important factors in family business's ownership behavior as stated by Garcia and Lopez (2006).

The results of this study are also strengthening the statement by Berent et al. (2012), Hall et al., (2008), Harveston et al., (1997) and Moris et al., (1996) abour the four types of ownership behavior, which are professionalism, active governance, owners as a resource, and basic duties.

First, professionalism is based on how far a business owner fulfills his/her role of duties and commitment in relationship to one another. Professionalism covers adherence to agreements between the owner himself/herself, and respect for the hierarchy and authority within the business.

Second, active governance, is referring to the monitoring of the management from the owner. Active governance focuses on the welfare of the company; thus, it can be expected to have a positive relationship with the financial performance.

Third, owners as a resource, reflects the owner's ability to provide the company's financial and nonfinancial resources.

Fourth, basic duties, owner's involvement include activities, such as attending shareholder meetings and reviewing the annual report that help the owner to keep up to date on the company's business activities. In addition, owner's participation in shareholder meetings can contributes to the business performance by providing suggestions on various topics (e.g. investment strategy, business succession planning, etc.). The owner can also reduce the risk of disunity that cannot be resolved by participating the meeting Kellermans et al., (2008), Miless and Huberman (1994). Shareholder meetings act to build a shared vision and mission for 
particular strategies, which both can bring a positive impact to business' performance.

\section{Conclusion}

Factor 1 is represented as professional governance, which consists of variables $\mathrm{X}_{1.1 .3}$ $\mathrm{X}_{1.1 .4}, \mathrm{X}_{1.2 .1}, \mathrm{X}_{1.2 .2}$ and $\mathrm{X}_{1.2 .3}$ which shows active governance and profession.

Factor 2 is represented as main duties, which consists of variables $X_{1.4 .1} X_{1.4 .2}$ and $\mathrm{X}_{1.4 .3}$ which shows basic duties factor.

Factor 3 is represented as owner responsibilities, which consists of variables $\mathrm{X}_{1.1 .4}$, $\mathrm{X}_{1.3 .1}, \mathrm{X}_{1.3 .3}, \mathrm{X}_{1.4 .4}$ and $\mathrm{X}_{1.4 .5}$ which mainly shows a mix of factors professional, owner resource, and basic duties.

Factor 4 is represented as professional activity, which consists of variables $\mathrm{X}_{1.1 .1}$ and $\mathrm{X}_{1.1 .2}$ which shows a mix of professional factor.

The study has found several indicators that build new variables of ownership behavior, which are professional governance, main duties, owner responsibilities, and professional activity in-line with other studies.

\section{Suggestion}

1. The lowest mean score and the highest standard deviation of respondents is found in indicator $\mathrm{X}_{1.1 .1}$ (the owner is involved in the internal business matters only if ihe/she has officially agreed that the job is part of his/her responsibility) with a standard deviation of 1.18202, which means that the average of respondents' answers is close to neutral with a diverse and variety of answers because of the high standard deviation. Thus, it needs another mechanism and procedure to improve the owner's involvement with the internal business affairs.

2. Future study should further investigate whether the ownership factor behavior, which is professional governance, main duties, owner responsibilities, and professional activity affects the business performance of family business.

\section{Acknowledgement:}

The Ministry of Research, Technology, \& Higher Education of Republic of Indonesia.

\section{References:}

Aminoff, P., Blom, A., Eco-Parssinen, K., Helkama, J., Koiranen, M., Nyman, K. and Paasikivi, K. 2004. On The Characteristics and Duties Involved in Responsible Ownership. Family Business Network Finland, Helsinki. 
Baer, G. 2007. Real Love in the Workplace: Eight Principles for Consistently Effective Leadership in Business. GA, Blue Ridge Press, Rome.

Baldacchino, J.P., Caruana, R., Grima, S. and Bezzina, H.F. 2017. Selected Behavioral

Factors in Client-Initiated Auditor Changes: The Client-Auditor Perspectives.

European Research Studies Journal, 20(2A), 16-47.

Basri, M.C. and Eng, P.V.D. 2004. Business in Indonesia: New Challenges, Old Problems. Singapore, ISEAS.

Berent-Braun, M.M. and Uhlaner, L.M. 2012. Responsible Ownership Behaviors and Financial Performance in Family Owned Businesses. Journal of Small Business and Enterprise Development, 19(1), 20-38.

Breton-Miller, I.L., Miller, D. and Steier, L.P. 2004. Toward an integrative model of effective FOB succession. Entrepreneurship Theory and Practice, 28(4), 305328.

Chittoor, R. and Das, R. 2007. Professionalization of management and succession performance - a vital linkage. Family Business Review, 20(1), 65-79.

Garcia, A.E. and Lopez, S.J. 2006. Founder-Successor's Transition: A Model of Coherent Value Transitions Paths, in Poutziouris, P., Smyrnios, K.X. and Klein, S.B. (Eds). Handbook of Research on Family Business. Edward Elgar Publishing Limited, Cheltenham and Northampton, 237-252.

Hair, J.A., Rolph, E.A., Ronald, L.T. and William, C.B. 1995. Multivariate Data Analysis With Readings. Engelewood Cliffs, N.J., Prentice-Hall, Inc.

Hall, Anika, and Nordqvist, M. 2008. Professional Management in Family Businesses: Toward an Extended Understanding. Family Business Review, 21(1), 51-68.

Handoyo, S.S. 2010. A Conceptual View of a Family-Owned Corporation. Makalah dalam Pelatihan yang diselenggarakan oleh Indonesia Institute for Corporate Directorship (IICD), Jakarta.

Harveston, P.D., Peter, S.D. and Julie, A.L. 1997. Succesion Planning in family Business: The Impact of Owner Gender. Family Business Review, 10(4), 373.

Kellermans, F.W., Kimberly, A.E., Tim, B. and Allison, P. 2008. An Exploratory Study of Family Member Characteristics and Involvement: Effects on Entrepreneurial Behavior in the Family Firm. Family Business Review, 21(1), 1-14.

Lansberg, I. 1999. Succeeding Generations: Realizing the Dream of Families in Business. Boston, Massachusetts, Harvard Business School Press.

Miles, M.B. and Huberman, A.M. 1994. Qualitative Data Analysis: an Expended Sourcebook (2nd ed.). Thousand Oaks, CA, Sage.

Morris, M.H., Williams, R.W. and Nel, D. 1996. Factors Influencing Family Business Succession. International Journal of Entrepreneurial Behaviour and Research, 2(3), 68-81.

PwC. 2015. 95 persen perusahaan Indonesia adalah bisnis keluarga. Jakarta: CNN Indonesia, http://www.cnnindonesia.com/ekonomi/20141202100356-9215176/pwc-95- persen-perusahaan-indonesia-adalah-bisnis-keluarga.

Utami, C.W., Bernardus, D. and Shinta, G. 2017. The Pattern Analysis of Family Business Succession: A Study on Medium Scale Family Business in Indonesia. European Research Studies Journal, 20(2A), 461-475.

World Bank Group. 2011. Family Business Governance Handbook. USA, International Finance Corporation. 